\title{
Union Density in Norway and Sweden: Stability versus Decline'
}

\section{Anders Kjellberg}

Professor of Sociology, Lund University, Sweden

\section{Kristine Nergaard ${ }^{2}$}

Researcher, Fafo Institute for Labour and Social Research, Norway

\begin{abstract}
The aim is to explain why union density is not only considerably higher in the Ghent country Sweden than in non-Ghent Nonway but also why it has declined much more in Sweden, in particular among blue-collar workers. We show how changes to Swedish unemployment insurance in 2007-2013 were followed by a decline in union density and how white-collar unions were more successful than blue-collar unions in developing supplementary income insurance schemes that counteracted membership losses. This type of institutional explanation is nevertheless insufficient. In Norway, too, blue-collar density has decreased while white-collar workers have maintained their density rate. Nonwegian data further show that even without unemployment insurance funds, it is possible to achieve a fairly high union density at workplaces with collective agreements. However, without unemployment benefits like we find in Sweden, it is increasingly challenging to establish an institutional foundation for a social custom of unionization.
\end{abstract}

\section{KEYWORDS}

Blue-collar workers / Ghent system / Norway / Sweden / trade unions / union income insurance / union density / white-collar workers

\section{Introduction}

he aim of this article is to explain why union density is not only considerably higher in Sweden (69\% in 2020) than in Norway $(51 \%)$, but also why it has declined four times more in Sweden compared to Norway since 2000. With some exceptions, the decline in both countries is concentrated among blue-collar workers. The relative stability of union density in the non-Ghent country Norway and the strong Swedish decline suggests that the remodeling of the Swedish Ghent system from 2007 may play a crucial role in this divergence in trends between the two countries. There are also reasons to assume that the growing blue-collar/white-collar unionization gap in Sweden is related to the reformed Ghent system, or more precisely to the considerable increase in fees for membership in union unemployment funds, in particular blue-collar funds, in 20072013. In addition, the introduction of supplementary union-run unemployment schemes can be expected to have the largest positive impact on white-collar union density. However, we may also have to look at other explanations to understand the increasing bluecollar/white-collar gap in union density. A clue is whether a similar development has taken place in Norway.

\footnotetext{
${ }^{1}$ You can find this text and its DOI at https://tidsskrift.dk/njwls/index.

${ }^{2}$ Corresponding author: Kristine Nergaard, Fafo. E-mail: kne@fafo.no.
} 
The lower Norwegian union density compared to Sweden is usually attributed to the non-existence of state-subsidized union-run unemployment funds. Apart from this, the similarities between Norwegian and Swedish industrial relations are conspicuous. That makes it extra interesting to study the impact of the institutional differences that do exist on union density, particularly the effects of the remodeled Swedish Ghent system. Compared to Sweden, Norway has weaker collective institutions in the labor market, understood here as unions, employer organizations, and the link between them - collective agreements. Specifically, there are more workplaces in the private sector with no collective agreement or union representation (Nergaard 2018). Consequently, there is good reason to examine the level and development of Norwegian union density overall as well as in workplaces with collective institutions such as collective agreements and trade unions.

We will examine and discuss the following hypotheses:

- An eroding Ghent system will result in a converging union density between the two countries. This effect will be strongest in sectors where many part-timers, fixed-term employed, and a high employee turnover make it harder to maintain a high coverage of union workplace representation and the social custom of unionization.

- An implication of the first hypothesis is that the eroding Ghent-effect and convergence in density rates is strongest for blue-collar workers. This expectation is strengthened by the observation that white-collar unions have been more successful in offering supplemental individual member benefits and their members have been less affected by the changes in the Ghent system.

- Collective institutions such as union presence and collective agreements at the workplace level can help sustain a high union density by providing services as well as a social custom to join the workplace level union. To investigate how union density is related to such institutions, we examine the unionization rate in enterprises that are bound by a collective agreement. ${ }^{1}$

\section{Background: Union organization in Norway and Sweden}

Since 2000, the share of unionized workers in Sweden has decreased four times more than in Norway, from $81 \%$ to $69 \%$, or by 12 percentage points, and from $53 \%$ to $51 \%$, or two percentage points, respectively (Table 1 ). Therefore, the density gap between the two countries decreased from 28 to 18 percentage points. Consequently, the rate of unionization in Sweden and Norway converged by 10 points.

Table I Union density in Sweden and Norway, 2000-2020. Percent and percentage points

\begin{tabular}{lcccccccccc}
\hline & $\mathbf{2 0 0 0}$ & $\mathbf{2 0 0 6}$ & $\mathbf{2 0 0 8}$ & $\mathbf{2 0 1 3}$ & $\mathbf{2 0 1 6}$ & $\mathbf{2 0 1 7}$ & $\mathbf{2 0 1 8}$ & $\mathbf{2 0 1 9}$ & $\mathbf{2 0 2 0}$ & $\mathbf{2 0 0 0 - 2 0 2 0}$ \\
\hline Sweden & 81 & 77 & 71 & 70 & 69 & 69 & 68 & 68 & 69 & -12 \\
\hline Norway & 53 & 51 & 50 & 50 & 50 & 50 & 50 & 50 & 51 & -2 \\
\hline Difference & 28 & 26 & 21 & 20 & 19 & 19 & 18 & 18 & 18 & -10 \\
\hline
\end{tabular}

Sources: Kjellberg 202 la-b (Sweden) and Nergaard 2020a (Norway). 
In Sweden, there has been a strong divergence between blue-collar and white-collar union density. In 2020, $73 \%$ of Swedish white-collar workers were union members but only $61 \%$ of blue-collar workers. That is a dramatic shift since 2006 , the year before the profound change of the Swedish Ghent system, when union density was $77 \%$ in both categories. This development is almost as evident in the public sector as in the private sector. Unlike in Sweden, the blue-collar/white-collar divergence did not increase very much in Norway (Table 4).

From an international perspective, the rate of unionization is high in both Sweden and Norway (Kjellberg 2021c). As the industrial relations systems have much in common, one might expect that a number of circumstances promoting a high union density are present in both countries, among them a tradition of cooperation between the labor market parties' (Andersen et al. 2014). The spirit of cooperation associated with the Swedish basic agreement of 1938 has actively promoted the high density of both trade unions and employers' associations. The Norwegian basic agreement came about almost simultaneously (1935). However, Norway never achieved the same density rates as Sweden, either among employees or employers.

The combined centralized and decentralized industrial relations system in the Nordic countries prevents a fragmentary coverage of collective bargaining and facilitates membership recruitment by the extensive network of 'union clubs' and shop stewards (Andersen et al. 2014; Kjellberg 2017). Face-to-face contact with union representatives and other union members maintains union membership as a social norm. Union workplace representation also makes it possible to achieve improvements directly in the workplace and provides protection for union members.

Another distinctive feature is the socially segregated union structure with separate national unions and confederations for blue-collar, professional, and other white-collar workers, which promotes cohesion within each group (Kjellberg \& Ibsen 2016). This pattern is less evident in Norway, where the blue-collar confederation has a considerably higher share of white-collar workers than its Swedish equivalent, although mainly in different trade unions. There is also a stronger tradition of white-collar unionization in Sweden than in Norway.

In contrast to Norway, Sweden has no statutory mechanism to ensure the general application of collective agreements. Despite this fact, $90 \%$ of Swedish employees (about $85 \%$ in the private sector) are covered by a collective agreement (Kjellberg 2021b). The high organization rate among Swedish employers plays a positive role in this regard. In Norway, less than one-half of private sector employees are in workplaces with collective agreements. One key explanation is the lower union density, which makes for fewer union demands for collective agreements. The unions are also unable to benefit from the fairly high associational density among private sector employers, as Norwegian employers' associations do not require their members to have a collective agreement (Alsos et al. 2021). This is also the case in Sweden, but members without collective agreements are much less frequent in Sweden than in Norway.

\section{Theoretical perspectives on union density}

When studying the impact of industrial relations institutions on union density, it is necessary to look at the circumstances that affect the decisions to join a union (Schnabel 
2003). Theories emphasizing the role of social norms and customs attach great importance to influence from union representatives, colleagues, friends, and relatives. The employer's attitude may also be important. In contrast, rational choice theory usually considers joining a union a completely individual decision based on a comparison of the costs and benefits of membership. While the costs usually refer to a sum of money (membership fees) benefits include much more than wages, namely other individual benefits such as insurance.

According to Calmfors et al. (2021), the need for job security occupies a prominent place among the utility motives for union membership in Sweden. To avoid standing alone in case of a dispute with an employer is the most important membership motive. The same is found in Norwegian studies (Nergaard 2020b). As collective agreements also cover non-union members, freeriding is possible. Consequently, positive selective incentives, such as supplementary union income insurance, may be important for membership recruitment. Among these, unemployment funds are highlighted as being of special importance. Although it is not necessary to be a union member to receive benefits from a union unemployment fund, many Swedish employees wrongly perceive it as a 'package', namely that membership in both the union and its fund is required (Calmfors et al. 2021). However, 'direct affiliation' to union funds (i.e., without union membership) is becoming more and more frequent, as shown in Table 3.

The two types of theories can be combined. According to social customs theory, social norms that encourage unionization are maintained at workplaces with high union density. It could, however, be argued that the establishment of such norms is largely dependent upon the presence of a union. Trade unions produce not only material goods and job security, 'but also social norms stipulating that employees should be members of a trade union' (Toubøl \& Jensen 2014: 139). In workplaces with a high share of union members, being non-affiliated might have social costs. Therefore, it will be rational to join a union where there is a strong tradition of doing so.

International comparisons show that strengthened union workplace representation has a positive impact on union density (Visser 2002: 423). For employees at workplaces without union representation, and consequently less social pressure to join, selective incentives, like union income insurance, can be expected to have a relatively greater impact. That is in line with Ebbinghaus et al. (2011: 120-121), who show that the effect of workplace representation on union density is smaller in Ghent countries than in other countries. Workplace representation will therefore be more important in Norway than in Sweden for maintaining a high union density. The Swedish union-run unemployment funds may partly fulfill a compensatory role in industries with weak workplace representation. Conversely, an eroding Ghent system would result in growing density differences between industries, declining union density, and weakened union representation at the workplace level.

Workplace clubs are based on the spatial proximity between workers, which is one of two basic sources of cohesion and common norms among workers highlighted by Lysgaard (2001). The other is similarity, which refers to workers with the same occupation or education. From a union perspective, proximity and similarity correspond to two organizational principles: the industry principle (vertical unions organizing all kind of workers at a workplace) and the occupational principle (occupational unions). Lysgaard uses the proximity and similarity principles to explain the emergence of an informal 'workers' collective' to resist employer demands for constantly increasing productivity. 
The workers' sharing of this problem is a third source of cohesion and common norms. A trade union performs similar tasks to a workers' collective but in a much more organized way. As in social customs theory, there is pressure on the workers to conform to the norms and act in solidarity with their fellow workers.

Norms to join unions can be expected to be weaker in workplaces without union representatives. Selective incentives to join unions in workplaces without union presence will therefore have a relatively greater significance, for example, union-run income insurance schemes, other insurance, and access to individual advice and legal assistance in disputes with the employer.

The principles of proximity and similarity combined could be expected to reinforce cohesion, particularly in white-collar unions which are also professional associations and large enough to have workplace clubs. Members have the same workplace, the same profession, and the same educational background. These types of unions not only represent their members as employees (wages, working conditions) but also defend their professional autonomy, ethics, methods, and quality of services (Ble-Drivdal 2020: 49). The last type of representation can be considered a selective incentive for membership.

\section{Data}

\section{Sweden}

In Sweden, union density is determined using questions in the Labor Force Survey (LFS). The question on union membership is standard. The LFS encompasses information on the employees' age, industry etc. The distinction between blue-collar and white-collar employees is based on the Swedish socio-economic classification of occupations by social status. In this article, we investigate employees in the 16-64 age group. Full-time students are not included, even when they have a part-time job. The figures are taken from Kjellberg (2021a-b). Information on members in the unemployment insurance schemes is taken from the Swedish Unemployment Insurance Inspectorate (IAF).

\section{Norway ${ }^{2}$}

The total Norwegian union density (Table 1 ) is measured using information from trade unions on the number of their members in employment (Nergaard 2020a). To describe how union density varies across different industries and employee groups, we use two different data sets. Questions about union membership have been included in some supplementary surveys to the LFS. Figures from the LFS are used in Table 4. For the other analyses, we have used a data set (2001-2019) based on administrative data from Statistics Norway (register data per November each year). We include only workers resident in Norway in the 16-64 age group. Students working fewer than 30 hours per week are excluded for purposes of comparison with the Swedish data. In the analyses based on registry data, we use tax exemption for union dues as an indicator of unionization.

Norwegian statistics no longer distinguish between blue-collar and white-collar occupations. To compare with Sweden, we have coded managerial and clerical occupations and other occupations that require higher education (STYRK-98 categories 1-4) 
as white-collar. All other occupations (STYRK-98 5-9) are coded as blue-collar. Where information about occupation is missing, we use level of education.

We also distinguish between enterprises that are bound by a collective agreement and all other enterprises. We know that enterprises that are members in the early retirement (AFP) scheme have a collective agreement. This indicator has been adjusted for a few industries that are bound by national collective agreements without affiliation with the AFP scheme. All enterprises in the public sector are coded as having a collective agreement.

\section{Sweden: declining Ghent effect and diverging blue-collar and white-collar union density}

In international comparisons, the Ghent effect is considered by far the most important factor explaining the very high union density in Denmark, Finland, and Sweden (Ebbinghaus et al. 2011). Membership in a union and its unemployment fund was long perceived as a 'Ghent package', and to some extent still is, although it has never been compulsory to join a union if you become a member of its unemployment fund. In Sweden, such 'direct affiliation' gained greater traction among private sector whitecollar workers from the late 1980s and spread in the 1990s to blue-collar workers and public sector employees. This development was a first indicator of the erosion of the Swedish Ghent system. The need to 'buy' the whole package was no longer taken for granted (Kjellberg 2021a). Individual cost-benefit calculations became more common. These include several options:

- Membership in a union and its unemployment fund ('Ghent effect')

- Membership in only the fund ('direct affiliation')

- Membership in only the union

- Non-membership

In the three Nordic Ghent countries, institutional changes further undermined the Ghent effect: in Finland through the introduction of an independent unemployment fund in the 1990s; in Denmark by the cross-occupational unemployment funds introduced in the early 2000s; and in Sweden through a considerable increase in fees for unemployment funds in 2007-2013 (Kjellberg \& Ibsen 2016). It became quite expensive to be affiliated with both a union and its unemployment fund. In addition, the center-right government abolished tax reductions for union membership (25\%) and fund membership $(40 \%)$. These changes further weakened the norm of joining a union, as they occurred during a period of growing individualism, which only reinforced this development (Kjellberg 2020).

From July 2008, fund fees were closely linked to the unemployment rate among the members of each fund. Due to higher blue-collar unemployment, the fees for bluecollar funds in general became considerably higher than those for white-collar funds. In the first two years of higher fees, the decline was almost as great among white-collar as among blue-collar workers, but since then union density has increasingly diverged. In 2020 , only $61 \%$ of blue-collar workers were unionized compared to $73 \%$ of whitecollar workers (Table 2). From 2006 to 2020, union density among blue-collar workers 
declined four times more (minus 16 percentage points) than white-collar density (minus four points). The difference is even larger in the private sector where blue-collar density is down by 17 points and white-collar density not at all. The decline among white-collar workers is almost entirely concentrated in the public sector.

Table 2 Blue-collar and white-collar union density in Sweden by sector, 2000-2020. Percent and percentage points

$20002006200720082010201320142017201820202006-2008-2013-$

202020132020

\begin{tabular}{|c|c|c|c|c|c|c|c|c|c|c|c|c|c|}
\hline \multicolumn{14}{|c|}{ Blue-collar } \\
\hline $\begin{array}{l}\text { Private } \\
\text { sector }\end{array}$ & 79 & 74 & 70 & 67 & 65 & 62 & 61 & 58 & 57 & 57 & -17 & -5 & -5 \\
\hline $\begin{array}{l}\text { Public } \\
\text { sector }\end{array}$ & 90 & 87 & 85 & 83 & 83 & 79 & 77 & 72 & 71 & 72 & -15 & -4 & -7 \\
\hline $\begin{array}{l}\text { Both } \\
\text { sectors }\end{array}$ & 83 & 77 & 74 & 71 & 69 & 66 & 64 & 61 & 60 & 61 & -16 & -5 & -5 \\
\hline \multicolumn{14}{|c|}{ White-collar } \\
\hline $\begin{array}{l}\text { Private } \\
\text { sector }\end{array}$ & 70 & 69 & 65 & 63 & 65 & 67 & 68 & 68 & 67 & 69 & 0 & +4 & +2 \\
\hline $\begin{array}{l}\text { Public } \\
\text { sector }\end{array}$ & 93 & 89 & 86 & 85 & 85 & 84 & 84 & 82 & 82 & 81 & -8 & -1 & -3 \\
\hline $\begin{array}{l}\text { Both } \\
\text { sectors }\end{array}$ & 79 & 77 & 73 & 72 & 73 & 73 & 74 & 73 & 73 & 73 & -4 & +1 & 0 \\
\hline
\end{tabular}

Note: Employees aged 16-64 years, excluding employed full-time students.

Source: Labor force surveys.

From the mid-1990s up to and including 2006, Swedish union density declined by less than one percentage point per year on average. Then it suddenly fell by six points in two years: from 77\% in 2006 to $71 \%$ in 2008 (Table 1). In 2007 and 2008, unions together lost 245,000 members - of which the blue-collar confederation LO accounted for 160,500. Union unemployment funds lost about 400,000 members.

Following heavy criticism, in 2014, the center-right government restored fund fees to about the pre-2007 level. Before that, blue-collar density in the private sector decreased by five percentage points from 2008 to 2013 at the same time as white-collar density increased by four points. This tendency, however, also continued after the years of raised and differentiated fund fees. From 2013 to 2020, blue-collar density declined by another five points in the private sector in which white-collar density grew by two points. As we will see, a new Ghent effect mainly including white-collar workers actively contributed to this.

\section{Union income insurance creates a new Ghent effect}

A positive selective incentive first introduced by white-collar unions has created a new Ghent effect - a union income insurance supplementary to the insurance run by the union unemployment fund. The latter provides benefits corresponding to $80 \%$ of the 
wage but only up to a fixed amount. Above that ceiling, the unemployed member can get supplementary benefits from the union income insurance, but that requires membership in both the union and its unemployment fund.

Since the largest Swedish union, the private sector white-collar Unionen, was founded in 2008 by a merger of Sif (manufacturing industry) and HTF (trade and other private services), it has recruited large numbers of members by virtue of its income insurance. This is reflected in the development of union density within its recruitment area. The white-collar union density in trade increased from 56\% to $67 \%$ between 2008 and 2020 thus surpassing its previous record of $62 \%$ in 2006 (Table 3). In contrast, bluecollar density in the same industry decreased from 57\% to 52\%, far below the 2006 level of $64 \%$. The blue-collar Union of Commercial Employees (LO) also has an income insurance policy, but it is much less efficient as a recruitment instrument due to generally low wages and many part-timers among its members.

In the manufacturing industry, the white-collar union density showed a modest increase from $76 \%$ in 2008 to $79 \%$ in 2020 (Table 3). That differs markedly from the blue-collar decline in manufacturing from $81 \%$ to $73 \%$. It was hardly a coincidence that in July 2019 IF Metall (LO) found it necessary to introduce an income insurance. It was perhaps not by chance that blue-collar union density in manufacturing between 2019 and 2020 increased from $72 \%$ to $73 \%$.

Table 3 Union density and direct affiliation to union unemployment funds in Sweden (selected industries), 2006-2020. Percent and percentage points

\section{$200620082010 \quad 20192020 \quad 2006-2008-2019-$}

20192020

2020

\begin{tabular}{|c|c|c|c|c|c|c|c|c|}
\hline \multicolumn{9}{|l|}{ Manufacturing } \\
\hline $\begin{array}{l}\text { Union density: } \\
\text { - blue-collar } \\
\text { - white-collar }\end{array}$ & $\begin{array}{l}84 \\
80\end{array}$ & $\begin{array}{l}81 \\
76\end{array}$ & $\begin{array}{l}79 \\
77\end{array}$ & $\begin{array}{l}72 \\
78\end{array}$ & $\begin{array}{l}73 \\
79\end{array}$ & $\begin{array}{c}-11 \\
-1\end{array}$ & $\begin{array}{l}-8 \\
+3\end{array}$ & $\begin{array}{l}+1 \\
+1\end{array}$ \\
\hline $\begin{array}{l}\text { Direct affiliation: } \\
\text { - IF Metall } \\
\text { - Unionen }\end{array}$ & $\begin{array}{l}8 \\
-\end{array}$ & $\begin{array}{c}8 \\
26\end{array}$ & $\begin{array}{l}10 \\
26\end{array}$ & $\begin{array}{l}>12 \\
>11\end{array}$ & $\begin{array}{l}>12 \\
>15\end{array}$ & $\begin{array}{c}+4 \\
-\end{array}$ & $\begin{array}{c}+4 \\
-11\end{array}$ & $\begin{array}{r}0 \\
+4\end{array}$ \\
\hline \multicolumn{9}{|l|}{ Trade } \\
\hline $\begin{array}{l}\text { Union density: } \\
\text { - blue-collar } \\
\text { - white-collar }\end{array}$ & $\begin{array}{l}64 \\
62\end{array}$ & $\begin{array}{l}57 \\
56\end{array}$ & $\begin{array}{l}57 \\
61\end{array}$ & $\begin{array}{l}52 \\
66\end{array}$ & $\begin{array}{l}52 \\
67\end{array}$ & $\begin{array}{l}-12 \\
-5\end{array}$ & $\begin{array}{r}-5 \\
+11 \\
\end{array}$ & $\begin{array}{r}0 \\
+1\end{array}$ \\
\hline $\begin{array}{l}\text { Direct affiliation: } \\
\text { - Union of Commerci } \\
\text { Employees } \\
\text { - Unionen }\end{array}$ & $\begin{array}{c}19 \\
-\end{array}$ & $\begin{array}{l}22 \\
26\end{array}$ & $\begin{array}{l}26 \\
26\end{array}$ & $\begin{array}{c}36 \\
>11\end{array}$ & $\begin{array}{c}39 \\
>15\end{array}$ & $\begin{array}{c}+17 \\
-\end{array}$ & $\begin{array}{l}+17 \\
-11\end{array}$ & $\begin{array}{l}+3 \\
+4\end{array}$ \\
\hline \multicolumn{9}{|c|}{ Hotel \& restaurant } \\
\hline $\begin{array}{l}\text { Union density: } \\
\text { - blue-collar }\end{array}$ & 52 & 40 & 36 & 27 & 34 & -25 & -6 & +7 \\
\hline $\begin{array}{l}\text { Direct affiliation: } \\
\text { - Hotel \& Restaurant } \\
\text { Union }\end{array}$ & 23 & 36 & 49 & 63 & 69 & +40 & +33 & +6 \\
\hline
\end{tabular}




\begin{tabular}{lcccccccc}
\hline & 2006 & $\mathbf{2 0 0 8}$ & $\mathbf{2 0 1 0}$ & $\mathbf{2 0 1 9}$ & $\mathbf{2 0 2 0}$ & $\mathbf{2 0 0 6}$ \\
$\mathbf{2 0 1 9}$ & $\begin{array}{c}\text { 2008- } \\
\mathbf{2 0 2 0}\end{array}$ & $\begin{array}{c}\text { 2019- } \\
\mathbf{2 0 2 0}\end{array}$ \\
\hline Construction & & & & & & & & \\
\hline $\begin{array}{l}\text { Union density: } \\
- \text { blue-collar }\end{array}$ & 81 & 73 & 71 & 62 & 58 & -19 & -15 & -4 \\
\hline $\begin{array}{l}\text { Direct affiliation: } \\
\text { Building Workers' Union }\end{array}$ & 5 & 9 & 13 & $33 / 37$ & 42 & +28 & + ca 29 & +5 \\
\hline
\end{tabular}

Note: Union density: employees aged 16-64 years, excluding employed full-time students. Source: Kjellberg (202la).

Far from all blue-collar unions offer income insurance; moreover, many such schemes have been introduced only recently. Such insurance is also more attractive for whitecollar workers as their wages are usually far above the ceiling for unemployment insurance. As the ceiling remained unchanged for many years and increasingly lagged behind wage increases, the attractiveness of income insurance increased (Lindellee 2021). The combined effect of lower white-collar fund fees (2007-2013) and more frequent and attractive income insurance has had a significant impact on the growing gap between white-collar and blue-collar union density.

The declining union presence at workplace level in both IF Metall and Unionen illustrates the importance of union income insurance. Between 2006 and 2020, the share of IF Metall members represented by a workplace club decreased from $69 \%$ to $64 \%$ (Kjellberg 2021a). Including union representatives at workplaces without clubs, the share of employed members at workplaces with union presence declined from $85 \%$ to $80 \%$. The share of Unionen members covered by workplace clubs or union representatives dropped from $59 \%$ to $52 \%$ in 2013-2019. That means a larger decline in a shorter time than for IF Metall. As a significantly higher share of Unionen members are employed at workplaces without union presence, they are likely less exposed to the social norms of joining a union. Nevertheless, Unionen grew much more than IF Metall between 2008 and 2020: Unionen +192,500 members (+48\%), IF Metall -62,900 members (-21\%). Fewer employed bluecollar workers in manufacturing explains some of the IF Metall losses, but the divergence in white-collar and blue-collar union density in manufacturing is impossible to explain without reference to the recruitment capacity of the Unionen income insurance and the absence of similar insurance through IF Metall until July 2019.

Several blue-collar unions have no income insurance schemes or introduced them very late due to a fear that high blue-collar unemployment during recessions risked making the insurance very costly. The Building Workers' Union (LO) experienced such a cost explosion during the financial crisis and had to abolish its income insurance in 2010. This union is among those with the largest union density declines: from $81 \%$ in 2006 to $58 \%$ in 2020 (Table 3). Conversely, the share of fund members directly affiliated to its unemployment fund rose from $5 \%$ to $42 \%$, indicating a partial collapse of the 'Ghent package' (membership in both a union and its unemployment fund).

In contrast, the share of workers directly affiliated to the Unionen fund declined in the period 2008-2019 from 26\% to around 10\% (Table 3). Directly affiliated fund members joined the union to gain access to the income insurance. The increase in directly affiliated fund members from 2019 to 2020 was caused by the raised ceiling for unemployment insurance from July 2020 making union income insurance schemes less 
attractive for white-collar workers. Not by chance, the number of Unionen members increased significantly during the first half of 2020 but not at all during the rest of the year.

Like IF Metall, also the Hotel and Restaurant Union (LO) introduced an income insurance schemes very late but with little if any effect. Had it been introduced earlier, it would hardly have stimulated membership growth, as wages in this industry were not much above the ceiling for the unemployment insurance. Many of these workers are only members of the unemployment fund and do not belong to the union. In 2020 seven of ten fund members were not affiliated to the union. From 2006 to 2019 union density declined from $52 \%$ to about $30 \%$ (Table 3). Consequently, the Ghent effect in this industry almost disappeared and union density took a big step towards the very low Norwegian level of about $20 \%$ (Table 7 ). Hotel and restaurant workers were among those with the lowest wages, highest proportion of fixed-term contracts and largest labor turnover and fund fee increases in 2007. The declining Ghent effect had particularly large consequences in this industry, which lacked a strong workplace union organization that could resist this process. From 2019 to 2020, union density increased, however, as many employees with fix-termed contracts (a low-density category) lost their jobs during the COVID-19 crisis.

As we have seen, the divergence in union density between blue-collar and whitecollar workers can be attributed to (1) the remodeled Ghent system with its strongly negative impact upon blue-collar union density and (2) the more frequent and attractive income insurance schemes among white-collar unions. A third explanation is that in the 2010s Sweden received a large number of labor migrants and refugees from nonEuropean countries, a low-density category overrepresented among blue-collar workers in the service sector.

\section{No positive blue-collar Ghent effect during the financial crisis but during the COVID- 19 crisis}

As in other Ghent countries, Swedish union density usually increases during recessions. In the early 1990s, both unemployment and union density increased significantly: union density by four percentage points. Conversely, during the preceding economic boom in the late 1980s union density declined by four points.

The remodeled Ghent system changed this pattern. The financial crisis did not result in increased union density (Table 2). Private sector blue-collar workers in particular were hit by rising unemployment reflected in high blue-collar fund fees. In 2010, the IF Metall fund fee was still twice as high as that of the white-collar Unionen fund. The private sector blue-collar union density declined by two percentage points from 2008 to 2010 while the white-collar density in the same sector increased by two points (Table 2).

The situation was quite different during the 2020 COVID-19 crisis. The linkage between fund fees and unemployment rates was abolished in 2014 and high unemployment no longer caused high fund fees. In particular, blue-collar fees were much lower than during the financial crisis. Between 2019 and 2020, union density increased by one percentage point for blue-collar as well as for white-collar workers. The rate of employees directly affiliated to union unemployment funds, however, increased still more. Membership in union unemployment funds grew three times more than union membership in 
2020: by 234,000 and 75,000 members respectively. Consequently, although most new fund members did not consider the Ghent package as an entity, enough did to cause the largest union growth in many years. The sudden insecurity associated with the pandemic was apparently the principal motive for joining unions and funds. Another contributing factor was that the government raised the benefits and made the insurance conditions more generous.

\section{Norway}

Norway has had a state-administered unemployment benefit since the late 1930s. Norwegian trade unions have thus not been able to draw on the support offered by unemployment insurance funds when it comes to recruiting new members. Recruitment takes place mainly in the workplace, the characteristics of which therefore affect the probability of workers organizing. Workplaces with a collective agreement usually have union representation, which increases the prospects for successful recruitment efforts. However, many workplaces lack collective agreements and union presence. The low union density in some industries and at small workplaces is the key explanation. This is reinforced by the Norwegian practice in the private sector that collective agreements to be implemented at the workplace level require at least $10 \%$ of relevant employees to be union members and a workplace union demanding an agreement. ${ }^{3}$ Since Norwegian employer organizations do not require their members to enter agreements, a relatively high organization rate among employers has failed to produce a higher collective agreement coverage (Alsos et al. 2021).

Norway has not experienced an institutional shock comparable to the Swedish Ghent system reform. Still, there have been some relevant institutional changes. Union members receive a tax deduction for their trade union membership fee. This rate was increased substantially from 2003 onwards. A study based on register data (2000-2012) found that the increased tax deduction rate contributed to a less steep decline in union density, with the largest effect in sectors with low union density rates (Barth et al. 2020). Since 2010, the nominal level of the tax deduction rate has been more or less stable. The most significant change related to collective bargaining is the use of extension of collective agreements, which has been an element of Norwegian working life since 2004. Extension may be used in sectors where foreign workers are subject to less favorable wage and working conditions than are usual in the industry. Usually only minimum wage rates and some other provisions are generalized, meaning that the negative effect on union density is expected to be relatively small. An evaluation of the extension system confirms only small effects on union density Benedictow et al. (2021).

Collective agreements and industrial relations largely function in the same way in Norway and Sweden. Assuming that union density is maintained by union presence to a much higher degree at workplaces with collective agreements (providing social custom and assistance from shop stewards) than those without, we would expect union density in these workplaces to be similar to that in Sweden. Furthermore, changes in the tax deduction rate mean that we might expect different development for the periods 2002-2009 (substantial increase in the value of the tax deduction) and 2010 onward (stability and gradual decrease in net value since the tax deduction rate is an absolute value, NOK 3850 from 2012 onward). 


\section{Development - union density}

In Norway, $51 \%$ of employees were union members in 2020 . The unionization rate has declined over time after reaching a peak of 57\% in 1990 (Nergaard 2020a). By 2000, it had fallen to $54 \%$, and declined further until around 2007. In the last decade, the unionization rate has remained stable at around $50 \%$. The stable Norwegian unionization rate conceals large differences between industries, sectors, and small versus large enterprises, and to some extent also between blue-collar and white-collar occupations (Nergaard 2018, 2020a). In 2017, union density in the public sector (80\%) was twice as high as in the private sector $(38 \%)$; see Table 4 .

Union density has declined in the private sector, most steeply among blue-collar workers, from $41 \%$ in 2001 to $35 \%$ in 2017 . Compared to 2001 , blue-collar workers in the public sector were also less frequently unionized in 2017; their union density declined by five percentage points over this period. Among white-collar workers, union density has remained stable in both sectors throughout the period.

Table 4 Union density in Norway 200 I-20 I7. Percent and percentage points

\begin{tabular}{|c|c|c|c|c|c|c|c|}
\hline & 2001 & 2004 & 2008 & 2013 & 2017 & $\begin{array}{c}2001- \\
2017\end{array}$ & $\begin{array}{c}2008- \\
2017\end{array}$ \\
\hline Blue-collar, private sector & 41 & 39 & 37 & 39 & 35 & -6 & -2 \\
\hline Blue-collar, public sector & 75 & 73 & 69 & 73 & 70 & -5 & -1 \\
\hline Blue-collar, total & 50 & 49 & 46 & 49 & 43 & -7 & -3 \\
\hline White-collar, private sector & 39 & 42 & 40 & 42 & 40 & +1 & 0 \\
\hline White-collar, public sector & 84 & 86 & 86 & 86 & 84 & 0 & -2 \\
\hline White-collar, total & 59 & 61 & 60 & 61 & 57 & -2 & -3 \\
\hline Private sector, total & 40 & 41 & 38 & 41 & 38 & +2 & 0 \\
\hline Public sector, total & 81 & 81 & 80 & 81 & 80 & -1 & 0 \\
\hline
\end{tabular}

Note: LFS employees $16-64$ years.

In private sector enterprises with a collective agreement, approximately $60 \%$ of employees were union members in 2019 (Table 5). The unionization rate among white-collar employees has remained stable in this group while declining slightly among blue-collar occupations. In 2006, the difference in unionization rate was seven percentage points in favor of the blue-collar workers, but by 2019 this difference had shrunk to five points.

The unionization rate is very low in enterprises without collective agreements, particularly for blue-collar occupations (14\% per 2019), but also among white-collar workers $(24 \%)$. The somewhat higher density among the latter indicates that whitecollar unionization depends on many different types of rationale, including factors outside the workplace.

Although union density remains fairly high in enterprises with collective agreements, the proportion of blue-collar workers found in such workplaces declined by three percentage points from 2006 to 2019. A contributory factor could be that unions in some industries fail to establish collective agreements in new enterprises (Alsos et al. 2021). The change can also be associated with labor force restructuring with fewer employees working in sectors where collective agreements dominate wage setting. 
Table 5 Union density Norway 2006-2019. Private sector. Percent and percentage points

\begin{tabular}{lcccccc}
\hline & $\mathbf{2 0 0 6}$ & $\mathbf{2 0 0 9}$ & $\mathbf{2 0 1 4}$ & $\mathbf{2 0 1 9}$ & $\mathbf{2 0 0 6 - 2 0 1 9}$ & $\mathbf{2 0 0 9 - 2 0 I 9}$ \\
\hline Blue-collar worker - CA & 66 & 66 & 64 & 63 & -3 & -3 \\
\hline Blue-collar worker - no CA & 14 & 13 & 13 & 14 & 0 & +1 \\
\hline Blue-collar worker - total & 41 & 40 & 38 & 38 & -3 & -2 \\
\hline $\begin{array}{l}\text { Share of blue-collar workers } \\
\text { in companies with CA }\end{array}$ & 51 & 51 & 49 & 48 & -3 & -3 \\
\hline White-collar worker - CA & 59 & 58 & 57 & 58 & -1 & 0 \\
\hline $\begin{array}{l}\text { White-collar worker - no CA } \\
\text { White-collar worker - total }\end{array}$ & 42 & 22 & 22 & 24 & 2 & +2 \\
\hline $\begin{array}{l}\text { Share of white-collar workers } \\
\text { in companies with CA }\end{array}$ & 51 & 50 & 39 & 40 & 0 & 0 \\
\hline
\end{tabular}

Employees aged 16 years and more, excluding full-time students. Administrative registers.

CA, collective agreement.

\section{Norway and Sweden - differences and similarities}

In this section, we discuss similarities and differences in union density in Norway and Sweden. In particular, we are concerned with the development with regard to groups of workers and industries with varying preconditions for sustaining high union density over time. Can we see the same trend in the two neighboring countries despite their different institutional frameworks, or is it more evident in Sweden and associated with the erosion of the Ghent system?

The Swedish figures show that a change in institutional arrangements - here the reformed Ghent system - can lead to a significant fall in union density. On the other hand, the figures for Norwegian enterprises that are bound by collective agreements show that irrespective of any Ghent system, it is possible to maintain a fairly high unionization rate where collective institutions are present at the workplace level. Nor is the decline of union density equally distributed in the labor market. In Sweden, the unionization rate has fallen considerably more among blue-collar than among whitecollar workers and much more than in Norway. One explanation is that the reform of unemployment insurance had greater impact where unions were unable to develop membership benefits that compensate for the increased fees for union unemployment funds.

Union density has also declined among Norwegian blue-collar workers, although to a much lesser extent than in Sweden (Tables 2 and 5). In Sweden, blue-collar density declined both before and after the reform of the Ghent system. This indicates that we need to look for further explanations for why trade unions are facing greater challenges in maintaining high union density in some groups and not in others.

The blue-collar/white-collar distinction is not the only feature worth highlighting when comparing the two countries. To elucidate the short-term effects of the institutional changes to the Ghent system, as opposed to more long-term structural changes in the labor market, we examine sub-groups that have varying preconditions for maintaining high union density. Both international and Nordic studies report a low unionization 
rate among young people, foreign-born workers and in parts of the service sector (Visser 2019). Are these groups also more exposed to a declining union density in Sweden and Norway? We compare young versus older people, immigrant versus domestic-born workers, and service sector industries versus those that have a long tradition of collective industrial relations and unionization.

Since most Swedish employees in the private sector work in workplaces with a collective agreement, it can be argued that Norwegian enterprises that are bound by a collective agreement most closely resemble the Swedish situation. What are the differences between Norway and Sweden when we only examine what can be referred to as 'unionized workplaces' in Norway?

\section{Young vs. older workers}

Young workers are often held up as a group that tends to have a lower unionization rate. One frequently cited explanation is that young people predominate in jobs and workplaces where the barriers to unionization are high (Visser 2019).

In Sweden, the unionization rate among workers aged 16-29 declined by about 15 percentage points from 2000 to 2019 (Table 6). Most of the decline occurred in the years 2000-2009. In the period when fund fees increased (2007-2013), union density declined significantly more among those aged 16-29 (minus 11 points) than among those aged 30-64 (five-six points). In Norway, no such decline among the youngest has occurred, although the unionization rate among younger workers is significantly lower than in Sweden.

The gap between Swedish and Norwegian unionization rates for the youngest workers was reduced from 28 percentage points in 2000 to 10 points in 2019. For the age group 25-29 years, the trend is approximately the same. The erosion of the Swedish Ghent system was thus followed by a considerable Swedish-Norwegian convergence with respect to young people, although some of it occurred before the remodeling of the Swedish unemployment insurance. If we only examine young Norwegian workers in workplaces with a collective agreement, comparing them with the same age group in Sweden, the unionization rates do not differ significantly.

In Norway, union density declined among the oldest rather than the youngest workers. In Sweden, the same type of decline occurred later - from 2009 to 2019 - while the unionization rate among the youngest workers stabilized.

Table 6 Union density by age, Sweden and Norway (in total and in workplaces with a collective agreement). Percent and percentage points

\begin{tabular}{lccccccc}
\hline & $\mathbf{2 0 0 0}$ & $\mathbf{2 0 0 6}$ & $\mathbf{2 0 0 9}$ & $\mathbf{2 0 1 4}$ & $\mathbf{2 0 1 9}$ & $\mathbf{2 0 0 0 - 2 0 0 9}$ & 2009-2019 \\
\hline Sweden total & & & & & & & \\
\hline 16-24 years & 52 & 46 & 35 & 35 & 35 & -17 & 0 \\
\hline $24-29$ years & 74 & 68 & 59 & 58 & 58 & -15 & -1 \\
\hline $30-44$ years & 82 & 77 & 72 & 71 & 68 & -10 & -4 \\
\hline $45-64$ years & 88 & 85 & 80 & 80 & 76 & -8 & -4 \\
\hline Total & 81 & 77 & 71 & 70 & 68 & -10 & -3 \\
\hline
\end{tabular}




\begin{tabular}{|c|c|c|c|c|c|c|c|}
\hline & 2000 & 2006 & 2009 & 2014 & 2019 & 2000-2009 & $2009-2019$ \\
\hline \multicolumn{8}{|c|}{ Norway total } \\
\hline 16-24 years & 24 & 22 & 24 & 24 & 25 & 0 & । \\
\hline 24-29 years & 43 & 43 & 44 & 45 & 48 & +1 & +4 \\
\hline 30-44 years & 56 & 52 & 52 & 52 & 54 & -4 & +2 \\
\hline 45-64 years & 66 & 64 & 63 & 61 & 60 & -3 & -3 \\
\hline Total & 55 & 54 & 53 & 52 & 53 & -2 & 0 \\
\hline
\end{tabular}

\section{Norway - workplaces with collective agreements}

\begin{tabular}{llllllll}
\hline $16-24$ years & 36 & 36 & 37 & 38 & 39 & +1 & +2 \\
\hline 24-29 years & 62 & 61 & 62 & 63 & 67 & 0 & +5 \\
\hline $30-44$ years & 73 & 70 & 70 & 70 & 72 & -3 & +2 \\
\hline $45-64$ years & 81 & 80 & 79 & 77 & 76 & -2 & -3 \\
\hline Total & 72 & 71 & 71 & 70 & 71 & -1 & 0 \\
\hline
\end{tabular}

Note: Employees aged 16-64 years, excluding employed full-time students.

Source: Sweden: Labor force surveys. Norway: Administrative registers.

\section{Blue-collar occupations in sectors with strong and weak collective traditions}

Structural changes in the labor market are often highlighted as an explanation for declining union density over time. While manufacturing and the public sector provide stable workplaces, frequently with local union representation, the situation is different in the retail, hotel, and catering industries. These employ many young people and many part-timers, have a high employee turnover, and include many small enterprises. In general, such characteristics tend to reduce the likelihood of unionization. Construction is another industry that has been described as a challenge for trade unions, perhaps especially in Norway, where it has been highlighted as an industry where organized working life is under pressure (Arnholtz et al. 2018).

In Sweden, union density has declined most in the construction, hotel, and catering industries, but notably also among blue-collar workers in manufacturing and the public sector. We can thus see that some industries appear to be more heavily affected than others.

In Norway, union density has declined in the same industries, but to a lesser extent than in Sweden. One exception is retail trade, where the union density has remained stable at a very low level over time. If we only include workplaces with a collective agreement, we find approximately the same union density as in Sweden. From this we can draw the conclusion that collective arrangements such as collective agreements (in Norway implicating trade union presence) help ensure a high union density. Further, the absence of a Norwegian Ghent system has had the most negative impact on union density in industries such as retail trade and accommodation and food services, where union workplace organization in general is weak, many part-timers are employed, employee turnover is high, etc. 
Table 7 Union density among blue-collar workers in Sweden and Norway (total and workplaces covered by collective agreements). Percent and percentage points

\begin{tabular}{|c|c|c|c|c|c|}
\hline & 2006 & 2014 & 2019 & $\begin{array}{c}\text { Change } \\
\text { 2006-2019 }\end{array}$ & $\begin{array}{c}\text { Change } \\
2014-2019\end{array}$ \\
\hline \multicolumn{6}{|l|}{ Sweden total } \\
\hline Manufacturing, etc. & 84 & 76 & 72 & -12 & -4 \\
\hline Construction & 81 & 67 & 62 & -19 & -5 \\
\hline Retail and wholesale trade & 64 & 53 & 52 & -12 & -1 \\
\hline Accommodation and food services & 52 & 29 & 27 & -25 & -2 \\
\hline Public sector & 87 & 77 & 72 & -15 & -5 \\
\hline \multicolumn{6}{|l|}{ Norway total } \\
\hline Manufacturing, etc. & 61 & 59 & 59 & -2 & 0 \\
\hline Construction & 36 & 31 & 32 & -4 & +1 \\
\hline Retail and wholesale trade & 25 & 25 & 27 & 2 & +2 \\
\hline Accommodation and food services & 24 & 24 & 21 & -3 & -3 \\
\hline Public sector & 71 & 70 & 70 & -1 & 0 \\
\hline \multicolumn{6}{|c|}{ Norway - workplaces with collective agreements } \\
\hline Manufacturing, etc. & 76 & 75 & 74 & -2 & -1 \\
\hline Construction & 68 & 64 & 64 & -4 & 0 \\
\hline Retail and wholesale trade & 53 & 50 & 51 & -2 & +1 \\
\hline Accommodation and food services & 45 & 48 & 46 & +1 & -2 \\
\hline
\end{tabular}

Note: Employees aged 16-64 years, excluding employed full-time students. For public sector in Norway, figures are for 2007, not 2006.

Source: Sweden: Labor force surveys. Norway: Administrative registers.

\section{White-collar workers - stability and Swedish uniqueness}

We have showed that the Swedish unionization rate for white-collar workers appeared to be less affected by the reformed Ghent system when compared to blue-collar workers. That was explained by lower fees to union unemployment funds and the introduction of more attractive supplemental insurance schemes than in the case of blue-collar unions. Swedish white-collar unions have also recruited large numbers of members in workplaces without union representation through their income insurance schemes. It is further reasonable to assume that for white-collar workers, the choice of joining a union will be less dependent on recruitment efforts in the workplace. Studies show, for example, that many white-collar workers are recruited when they are still students (Nergaard et al. 2020b). A decision to join to become part of a professional community will also depend less on the presence of trade union representatives and activities in the workplace.

In both Sweden and Norway, white-collar union density today is about the same as in 2006, the year preceding the remodeling of the Swedish Ghent system, but with one 
exception. In the Swedish public sector, white-collar unionization rates have declined by eight percentage points, albeit from a very high level (Table 2).

Being in a workplace with a collective agreement appears to have less effect for white-collar than for blue-collar workers in Norway, even though union density among white-collar occupations is higher in enterprises with a collective agreement than in the private sector in general. Swedish private sector white-collar workers have a far higher unionization rate (almost 70\%) than their Norwegian colleagues (about $40 \%$ ), including those who work in an enterprise with a collective agreement (less than $60 \%$ ). This lends support to the assumption that Swedish white-collar unions recruit members based on both individual benefits (like supplementary income insurance - 'the new Ghent effect') and collective norms.

\section{Employees by national origin}

National origin is often used as a characteristic to explain differences in unionization rates. Newcomers in the Nordic labor market can be supposed to have a limited knowledge of trade unions and collective agreements. Furthermore, foreign-born blue-collar workers are often overrepresented in industries with a low union density. However, Sweden has been an exception in this regard: domestic-born and foreign-born bluecollar workers had the same unionization rate $(77 \%)$ in 2006 . Since then, union density has declined twice as much among foreign-born blue-collar workers as among domesticborn, and in 2019 the unionization gap had grown to 13 percentage points.

In Norway as well, union density is significantly lower among foreign-born workers compared to their domestic-born counterparts. In 2019, this gap amounted to 12 percentage points among blue-collar workers or roughly the same as in Sweden. The difference between these two groups has remained fairly stable over time. If we examine only employees in enterprises with a collective agreement, the unionization rate among foreign-born workers has remained stable from 2007 till 2019.

Table 8 Union density among blue-collar and white-collar workers by country of birth, Sweden and Norway 2006-2019. Percent and percentage points

\begin{tabular}{|c|c|c|c|c|c|c|}
\hline & & $\begin{array}{l}2006 \text { (SE), } \\
2007 \text { (NO) }\end{array}$ & 2013 & 2019 & $2006-2019$ & $2013-2019$ \\
\hline \multicolumn{7}{|c|}{ Sweden total } \\
\hline \multirow{2}{*}{ Blue-collar } & Foreign-born & 77 & 60 & 51 & -26 & -9 \\
\hline & Domestic-born & 77 & 67 & 64 & -13 & -3 \\
\hline \multirow{2}{*}{ White-collar } & Foreign-born & 70 & 65 & 65 & -5 & 0 \\
\hline & Domestic-born & 77 & 75 & 74 & -3 & -1 \\
\hline \multicolumn{7}{|c|}{ Norway total } \\
\hline \multirow{2}{*}{ Blue-collar } & Foreign-born & 36 & 33 & 37 & +1 & +4 \\
\hline & Domestic-born & 50 & 49 & 49 & -1 & 0 \\
\hline \multirow{2}{*}{ White-collar } & Foreign-born & 47 & 43 & 48 & +1 & +5 \\
\hline & Domestic-born & 59 & 58 & 60 & -1 & +2 \\
\hline
\end{tabular}


Table 8 (Continued)

\begin{tabular}{|c|c|c|c|c|c|c|}
\hline & & $\begin{array}{l}2006 \text { (SE), } \\
2007 \text { (NO) }\end{array}$ & 2013 & 2019 & 2006-2019 & 2013-2019 \\
\hline \multicolumn{7}{|c|}{ Norway - workplace with collective agreements } \\
\hline \multirow{2}{*}{ Blue-collar } & Foreign-born & 54 & 54 & 58 & 0 & +4 \\
\hline & Domestic-born & 70 & 69 & 68 & -2 & -1 \\
\hline \multirow{2}{*}{ White-collar } & Foreign-born & 60 & 58 & 64 & +4 & +6 \\
\hline & Domestic-born & 75 & 74 & 75 & 0 & +1 \\
\hline
\end{tabular}

Note: Employees aged 16-64 years, excluding employed full-time students.

Source: Sweden: Labor force surveys. Norway: Administrative registers.

The substantial decrease in union density among foreign employees in Sweden corresponds to a period when large numbers of refugees arrived in Sweden. Between 2013 and 2019, the decline of union density among foreign-born workers was three times larger than among domestic-born workers.

The impact of foreign-born workers on blue-collar union density in total is in a class of its own due to the rapidly growing share of foreign-born workers among blue-collar workers, combined with lower (Norway) or considerably faster union member decline (Sweden) among foreign-born compared to domestic-born workers.

One key question is what happens with immigrant workers over time. Norwegian analyses show that their unionization rate grows steeply with increasing time of residence in the country, and that the gap between domestic-born and foreign-born workers decreases as the latter group's time of residence increases (Nergaard et al. 2015). However, this presupposes that immigrant workers are not systematically overrepresented in industries with weak collective institutions such as low coverage of collective agreements or workplaces without union representation. According to a Norwegian study, can the immigrants' composition (gender, age), labor market position (industry, firm size, working hours), and skills explain two-thirds of the immigrant-native gap in unionization (Cools et al. 2020:36). The relative concentration of foreign-born to lowunionized workplaces implies in both countries a relatively weak exposure for social customs encouraging union membership.

\section{Discussion and conclusion}

Sweden and Norway have seen different trends in union density - decline and stability respectively - resulting in a certain convergence between the two countries, although Swedish unions still organize a significantly higher share of employees (almost $70 \%$ ) than Norwegian unions (about 50\%). The most dramatic development occurred over the years 2007 and 2008 when Swedish unions lost 245,000 members and the rate of unionization fell from $77 \%$ (2006) to $71 \%$ (2008). Such a large decline in two years is also remarkable from an international perspective. Since then, the average Swedish union density has been relatively stable.

The significantly lower level in Norway is often explained by the fact that the Ghent system was abandoned there in 1938. Our review has shown, however, that the trends in union density are more complex. The decline in union density varies between 
different groups in the labor market, and Norwegian workplaces that are covered by a collective agreement (seen as a proxy for presence of union representation) have a high union density even without such individual benefits as the Swedish unemployment insurance scheme. To explain stability versus change in union densities, we therefore need to assume that the institutions in working life affect different groups of workers differently.

First, we find that in both countries the decline in union density has occurred mainly among blue-collar workers, particularly in Sweden, where this decline continued after the period of considerably increased union unemployment fund fees (2007-2013). After a fall from $77 \%$ in 2006 to $66 \%$ in 2013 , blue-collar union density dropped further to $60 \%$ in 2019, which means a decline of 17 percentage points compared to 5 in Norway and consequently a blue-collar convergence between the two countries, as expected in hypothesis 1 . Swedish blue-collar union density increasingly diverged from that of white-collar workers among whom the decline ceased. We have highlighted some institutional explanations. The reform of the Swedish Ghent system meant that potential members' cost-benefit calculations became extremely unfavorable for blue-collar unions as the total fee for union and union fund membership could be very high, while members in general had the lowest wages in the labor market. Due to low wages, blue-collar unions also failed to establish supplementary union income insurance with the capacity to recruit many members. In Norway, institutional factors also explain part of the decline. Union density is relatively high in Norwegian workplaces that have a collective agreement, which indicates that workplace traditions (social customs) help recruit members and that the weakening of such traditions makes recruitment more difficult. We nevertheless need to look for other explanations to fully understand the blue-collar density decline in the two countries. It is thus natural to examine structural changes in the labor market, such as the increasing share of immigrant workers who are less familiar with the collective institutions in Nordic working life or shifts in employment between industries and forms of employment. Such changes may weaken certain social customs, namely the tradition of unionization, especially among blue-collar workers. High employee turnover, lower union density in workplaces, fewer employees in workplaces with local union branches or representatives, and more part-timers are characteristics that can presumably affect the 'social glue' in workplaces.

Second, union density has declined steeply among some groups in Sweden: young people, blue-collar workers in some industries (construction, hotel, and catering), and immigrants in blue-collar occupations. These groups are already characterized by low union density in Norway. Thus, it may appear as though the weakened incentives in the Swedish Ghent system, combined with characteristics of industries and workers that hinder unionization, have strongly affected Swedish union density resulting in a Swedish/Norwegian convergence. Moreover, experience from Norway indicates that the union density in these groups may erode even further, given that collective institutions in the form of collective agreements have been weakened in industries with many young people, many workers from immigrant backgrounds, etc. On the other hand, in both countries we can see that unionization rates are markedly higher in the age group 25-29 years than among the youngest workers (below 25 years). In general, the distance between young adults (25-29 years) and the older groups has not increased if we look at the situation in the years from 2000 to 2018-2019. In Norway, we also find relatively stable unionization rates among workers from an immigrant background, despite an increase in the proportion of immigrant workers in recent years. Although the gap in 
unionization rates between domestic-born and foreign-born workers persists, the figures indicate that many foreign-born workers are included in trade unions after spending some time in the Nordic labor market.

Third, union density has largely remained stable among white-collar workers. The Swedish public sector is an exception, but here, union density has fallen from a level that was extremely high to begin with. In Norway, union density has remained stable among white-collar workers, in the private and public sectors alike. Our second hypothesis wherein we expected less convergence in union density among white-collar workers - is therefore supported. This indicates that unions of this type have multiple strategies at their disposal to maintain high union density, which Swedish white-collar unions have drawn on to counteract the negative Ghent effect. We have devoted much attention to the income insurance schemes that were introduced by Swedish white-collar unions. However, this type of measure has not influenced all white-collar workers. The lower risk of unemployment in the public sector limits the recruitment potential of such insurance schemes. Swedish white-collar density in the private sector was almost the same in 2020 as in 2000 whereas it declined by 12 percentage points in the public sector (Table 2). A supplemental explanation, which also can account for the stable white-collar density rate in Norway, is that unlike blue-collar workers, white-collar occupations are less affected by structural changes in the labor market that serve as obstacles to unionization as they have a lower prevalence of temporary employment and fewer foreign-born workers who are new to the country. Many white-collar unions also double as professional associations that permit members to retain their membership after shifting from student to professional status or transferring to another industry or sector. Drawing on Lysgaard (2001), we argue that the similarity between the members of a professional group (the same profession and the same education) constitutes a source of cohesion promoting union membership. At the same time, we find that the Swedish tradition of strong white-collar unions in the private sector has given rise to a union density among white-collar workers that their Norwegian counterparts cannot match, even in workplaces with a collective agreement. This tradition of private sector white-collar unionization is thus a distinctive feature of Swedish working life. The largest of these white-collar unions, the non-professional 'vertical' Unionen, which, through intense campaigns for its supplementary income insurance has recruited large numbers of members, including at workplaces without union presence. The second largest white-collar membership in the private sector is found in the Association of Graduate Engineers, which attracts members with both its professional character and its income insurance. In Norway, the two unions for engineers (TEKNA and NITO) are the principal white-collar unions in the private sector.

Fourth, while the Ghent system has helped achieve the high union density found in Sweden, collective institutions in the workplace are also important. Today, there are only minor differences in union density between the two countries when we look at the public sector. In the private sector, Norwegian enterprises that have signed a collective agreement have approximately the same union density as Sweden seen as whole. We have no figures for union density in Swedish enterprises that have a collective agreement, but the coverage rate has remained at a consistently high level over time about $85 \%$ of Swedish private sector employees are covered by collective agreements. Although high union density can be maintained by collective institutions and social customs at the workplace level, as predicted in hypothesis three, the Ghent system has

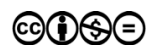


played an important role in establishing such institutions and traditions. In Norway, on the other hand, we find many workplaces with no collective agreement and no trade union representation. Here, the absence of a Ghent system is of importance, especially in the service sector with its many part-timers and high employee turnover. This is obvious in trade with a blue-collar density about $25 \%$ in Norway compared to about $50 \%$ in Sweden.

\section{References}

Alsos, K., Nergaard, K. \& Svarstad, E. (2021). Arbeidsgiverorganisering og tariffavtaler. [Collective organisation of employers and collective agreements], Oslo: Fafo-rapport 2021:7.000.

Andersen, S. K., Dølvik, J. E. \& Ibsen, C. L. (2014). Nordic labour market models in open markets, Brussels: ETUI.

Arnholtz, J., Meardi, G. \& Oldervoll, J. (2018). Collective wage bargaining under strain in northern European construction: resisting institutional drift? European Journal of Industrial Relations 24(4): 341-356. doi: https://doi.org/10.1177\%2F0959680118790816.

Barth, E., Bryson, A. \& Dale-Olsen, H. (2020). Hva betyr skattefradraget for oppslutningen om fagforeninger? [How does tax deduction affect union membership?] Søkelys på arbeidslivet. 01-02 / 2020 (Volume 37). doi: https://www.idunn.no/doi/full/10.18261/ issn.1504-7989-2020-01-02-07.

Benedictow, A. et al. (2021). Evaluering av ordningen med allmenngjøring av tariffavtaler. [Evaluation of the scheme for generalization of collective agreements]. Samfunnsøkonomisk analyse. Rapport $13-2021$.

Calmfors, L., Nederberg, J. \& Persson, C. (2021). Vad finns det för anledning att vara med $i$ facket? [Why become a union member?]. Stockholm: Fores.

Cools, S., Finseraas, H. \& Rasmussen, M. B. (2020). The Immigrant-Native Gap in Union Membership, Labour 35(1): 24-51. doi: https://doi.org/10.1111/labr.12186.

Ebbinghaus, B., Göbel, C. \& Koos, S. (2011). Social capital, 'Ghent' and workplace contexts matter: comparing union membership in Europe, European Journal of Industrial Relations 17: 107-124. doi: https://doi.org/10.1177/0959680111400894.

Ble-Drivdal, A. (2020). Unions conceptualizations of members' professional interests and influence in the workplace, Nordic Journal of Working Life Studies 10(4): 43-63. doi: https://doi.org/10.18291/njwls.122188.

Kjellberg, A. \& Ibsen, C. L. (2016). Attacks on union organizing: Reversible and irreversible changes to the Ghent-systems in Sweden and Denmark. In Larsen, T. P. \& Ilsøe, A. (eds.) Den danske model set udefra [The Danish model - Inside Out], Copenhagen: Jurist- og Økonomforbundets Forlag, 279-302. https://portal.research.lu.se/en/publications/attacks-on-union-organizing-reversible-and-irreversible-changes-t.

Kjellberg, A. (2017). Self-regulation versus State Regulation in Swedish Industrial Relations. In Rönnmar, M. \& Julén Votinius, J. (eds.) Festskrift till Ann Numbauser-Henning [Festschrift for Ann Numhauser-Henning], Lund: Juristförlaget, 357-383. https://portal. research.lu.se/sv/publications/self-regulation-versus-state-regulation-in-swedish-industrial-rel.

Kjellberg, A. (2021a). Den svenska modellen 2020: pandemi och nytt huvudavtal [The Swedish model in 2020: pandemics and new basic agreement], Stockholm: Arena Idé https:// portal.research.lu.se/portal/en/publications/den-svenska-modellen-2020-pandemi-ochnytt-huvudavtal(bf71341d-dc03-4983-9287-4093d2a47e4c).html. 
Kjellberg, A. (2021b). Kollektivavtalens täckningsgrad samt organisationsgraden hos arbetsgivarförbund och fackförbund [The Coverage of Collective Agreements, Union Density and Density of Employers' Associations], Department of Sociology, Lund University (Appendix 3 in English). https:/portal.research.lu.se/portal/en/publications/kollektivavtalens-tackningsgrad-samt-organisationsgraden-hos-arbetsgivarfoerbund-och-fackfoerbund(384bb031-c144-442b-a02b-44099819d605).html.

Kjellberg, A. (2021c). The shifting role of unions in the social dialogue, European Journal of Workplace Innovation 6(1-2): 220-244. https://portal.research.lu.se/sv/publications/theshifting-role-of-unions-in-the-social-dialogue.

Lindellee, J. (2021). Transformation of the Ghent system in Sweden: silent institutionalization of complementary unemployment benefits, Nordic Journal of Working Life Studies. doi: https://doi.org/10.18291/njwls.123605.

Lysgaard, S. (2001). Arbeiderkollektivet [The Workers Collective], Oslo: Universitetsforlaget. Nergaard, K. (2020a). Organisasjonsgrader, tariffavtaledekning og arbeidskonflikter 2018/2019. [Trade union and employer' organization density, collective agreement coverage and industrial conflicts 2018/2019] Fafo-notat 2020:12.

Nergaard, K. (2020b). Holdninger til fagorganisering. En undersøkelse blant lønnstakere. [Attitudes towards trade union organization. A survey among employees.] Fafo-rapport 2020:33.

Nergaard, K. (2018). Organisasjonsgrader, tariffavtaledekning og arbeidskonflikter 2016/2017. [Trade union and employer' organization density, collective agreement coverage and industrial conflicts 2016/2017] Fafo-notat 2018:20.

Nergaard, K., Barth, E. \& Dale-Olsen, H. (2015). Lavere organisasjonsgrad, et spørsmål om nykommere? [Declining union density rates - a matter of newcomers in the labour market?] Søkelys på arbeidslivet, 01-02 / 2015 (Volume 32). doi: https://www.idunn.no/ doi/10.18261/ISSN1504-7989-2015-01-02-06.

Schnabel, C. (2003). Determinants of trade union membership. In J. T. Addison and C. Schnabel (eds.) International Handbook of Trade Unions. Cheltenham, Edwin Elgar, 13-43.

Toubøl, J. \& Jensen, C. S. (2014). Why do people join trade unions? The impact of workplace union density on union recruitment, Transfer 20(1): 135-154. doi: https://doi. org/10.1177\%2F1024258913516902.

Visser, J. (2002). Why fewer workers join unions in Europe: a social custom explanation of membership trends, British Journal of Industrial Relations 40(3): 403-430. doi: https:// doi.org/10.1111/1467-8543.00241.

Visser, J. (2019). Trade Unions in the Balance. ILO ACTRAV Working Paper, Geneva.

\section{Notes}

${ }^{1}$ To do so, we must look beyond LFS data and use administrative data.

${ }^{2}$ The Norwegian data is based on Fafo's research program on union density, collective agreements and labor market outcomes.

${ }^{3}$ This applies to blue-collar workers at workplaces with at least 25 employees within the relevant occupations. 